\title{
COVID-19 AND ITS IMPACT ON DISINFORMATION AND FAKE NEWS
}

\author{
International Black Sea University \\ David Agmashenebeli Alley, 2, 13th km., Tbilisi, 0131, Georgia \\ E-mail: mikiashvilisalome@gmail.com
}

\begin{abstract}
Purpose: the purpose of the study is to critically evaluate the disinformation spread by different state interested groups during the corona virus pandemic and it's concequences. The methodological basis of the research comprises philosophical, ideological, general scientific and special methods. Results: Corona Virus Pandemic was so unexpectable for World. Coronavirus gave rise to a new online era. The world has shifted to existence in the virtual mode, which in turn caused new difficulties. the more the disinformation will substitute the authoritative legal sources the greatest threat it becomes for public health and political order. The author exemines the effectivness of the measures taken by the US and EU countries taken during Corona virus pandemic to combat spread of disinformation. Discussion: raising awareness about disinformation and Covid-19 to reduce spread of fake news, search for actions to be taken while dealing with the spread of disinformation.
\end{abstract}

Keywords: disinformation; interest groups; Covid-19; pandemic; Russia; fake news.

Problem statement and its relevance. The motive of sharing the fake news is strictly political but spreading disinformation and misinformation about COVID-19, though not always a criminal offence, has very serious consequences, endangering public health and directly affecting people's lives. In the pandemic situation the Kremlin still uses panic and fear in the public for political goals which forces countries that are targeted by Russian propaganda to fight both the coronavirus pandemic and the Fake news. Fake news about COVID-19 have huge impact on average EU citizens looking for advice and support from others on social media.

Purpose of the article: to reveal the disinformation concerning the Coronavirus and the information harmful for people and explore the mechanisms that EU and U.S are using to combat the disinformation coming from Russia.

The presentation of the main material. Corona Virus Pandemic was so unexpectable for World. Coronavirus gave rise to a new online era. The world has shifted to existence in the virtual mode, which in turn caused new difficulties. Governmental and non-governmental organizations, private organizations and businesses have switched to dis- tance working mode. Consequently, cybercriminals have also become more active. With the growth of cybercrime, the amount of disinformation related to the state interests has also increased.

More than $90 \%$ of the world population is in partial or full self-isolation. Factories, shopping malls, restaurants, cafes, cinemas and theatres are closed. While the world seems to have stopped, Russian disinformation works twice as hard directing conspiracy theories and fake news to the new coronavirus.

The messages first appear in the Russian media, which later serves as a basis for Georgian media. The information is distributed systematically, involving Facebook pages and specific people, who frequently voice Kremlin messages.

Fake news on COVID-19 circulating in Georgia is political in nature and spread by openly proRussian as well as Georgian-language news outlets. Key messages conveyed through it are:

- Virus is man-made, manufactured by the USA; some of the outlets assert that the Lugar Lab is the source of virus;

- The role of the Lugar Lab in the fight against pandemic is overstated; 
- The EU has abandoned Italy; EU flags are removed in Italy and France;

- Only authoritative countries (Russia, China) can cope with the pandemic;

- Americans ask for forgiveness of coronavirus sins through prayers;

- Coronavirus is linked to masons;

- Bill Gates plans to fight coronavirus by implanting microchips on a large scale;

- Russians created a medication against coronavirus [5].

The deliberate dissemination of disinformation about public health threats is nothing new. Even during the cold war, the Soviet-era information campaign claimed that the United States intentionally spread HIV virus. The campaign was called "Operation Infection" and the articles developed the conspiracy theory that the virus causing HIV infection was secretly created in the biological laboratories of the United States and was now tested on people. At the time, this information campaign was conducted by Russian security services, the socalled KGB.

The same tendency is observed with the spread of the Coronavirus. Accusations against the United States first appeared in marginal pro-Kremlin media, and then in pro-Kremlin mainstream media. It also spread by means of Russian politicians and social media platforms such as Youtube and Vkontakte.

For instance, the marginal pro-Kremlin media accuses U.S of using biological weapons against China and says that the United States are using economic and militaristic weapons to put pressure on its rival China.

Another myth of Russian disinformation concerns the Lugar Laboratory in Tbilisi. REN-TV spread the fake information, according to which the Lugar Laboratory is one of the bases of the United States, where biological weapons are created and implied that the Coronavirus was also invented here. It is not the first occasion when the Lugar Laboratory has become the target of disinformation. Earlier, according to EUvsDisinfo, the laboratory became the source of the spread of Hepatitis C.

Online edition of "Tabula", which in turn relies on AFP, states that Pro-kremlin media is closely followed by the fake accounts in social media. The
US Department of State has identified thousands of social media accounts connected to Russia, which acted in a coordinated manner to cause panic over Coronavirus, spread disinformation and undermine the global efforts to fight the epidemic.

As AFP reports, some of the accounts were spreading false information about how the United States wages "economic war" with China and that this virus is the biological weapon created by CIA. According to AFP, the report of the US Department of State says that these fake social media profiles are not managed by bots but by people, and are simultaneously posted in English, Spanish, Italian, German and French Languages.

The disinformation about Coronavirus alleging that the Ministry of Health of Ukraine published a letter reporting five cases of virus infection, resulted in protest demonstrations in Ukraine. It was later established that the letter had been written outside of Ukraine, but the citizens were already demanding that their fellow citizens, already evacuated from Wuhan, be denied entry into Ukraine. Fear, disinformation and low level of trust in government is fertile grounds used by pro-Kremlin media.

Facebook says that it will delete the disinformation concerning the Coronavirus and the information harmful for people, for instance information about drinking the bleach allegedly being the cure for Coronavirus. Instagram will also block and limit the hashtags used for spreading disinformation. Apart from this, in order to raise awareness, the company will provide its users with information about the virus in different ways [10].

"EU monitoring team also collected 80 examples of disinformation from Russian sources in nearly two months up to 16 March. Coronavirus was claimed to be a biological weapon deployed by China, the US or the UK. Other conspiracy theories contended the outbreak was caused by migrants or was a pure hoax. An internal EU network, where member states share cases, also reported examples of disinformation. In Lithuania there were false claims that a US soldier deployed to the country had been taken to hospital with coronavirus [8].

"Russia has flatly denied allegations that it is spreading disinformation about the new coronavirus outbreak on social media. "This is a deliberately 
false story," foreign ministry spokeswoman Maria Zakharova told Russia's Tass news agency [1].

Russia itself on contrary began the campaign of fines after an opposition-leaning radio station in Russia interviewed political analyst Valery Solovei, who alleged the government was lying when it said no one had died in the country from the coronavirus. Fines are up to $\$ 25,000$ and prison terms of up to five years for anyone who spreads what is deemed to be false information. Media outlets will be fined up to $\$ 127,000$ if they disseminate disinformation about the outbreak.

The head of the Russian Investigations Committee (SKR), Alexander Bastrykin, has issued instructions to set up a working group to identify "false information on the Internet about the spread of coronavirus in the country." Moscow is heavily reliant on facial recognition and other tracking technologies to enforce the lockdown, generating fears in opposition quarters that the surveillance measures may be made permanent and result in a "digital dictatorship." [4].

The crusade began about a month ago, when Russia's caseload was still in the single digits. The Kremlin's stance of "everything is under control" prompted speculation that authorities might be hiding or underreporting the scale of the outbreak in line with Soviet-era traditions of covering up embarrassing truths. A broad set of measures was outlined and a special "fake news" division in the government's coronavirus task force was created. A group within Russia's Investigative Committee was put together to chase down alleged disinformation.

Social media users who doubted the official numbers and news outlets questioning the government response became targets for law enforcement seeking to weed out anything that didn't correspond with the official data.

The AP found at least nine cases against ordinary Russians accused of spreading "untrue information" on social media and via messenger apps, with at least three of them receiving significant fines.

Police statements offered few details but clearly indicated those involved were merely sharing opinions or rumors, rather than deliberately spreading misinformation.
The crackdown on free speech fits a recent pattern. In the past five years, hundreds of people have been prosecuted on charges of extremism for posting, liking or sharing information on social media on sensitive topics like corruption, the conflict with Ukraine, the 2014 annexation of Crimea and the role of the Russian Orthodox Church. Dozens received prison sentences [3].

As we already mentioned cyber criminals have targeted citizens with fake coronavirus-related products and services and public can play the vital role in fighting against the disinformation by not sharing and commenting on the false information. Public needs to realise that power is in their heands and that spreading disinformation and misinformation about COVID-19, though not always a criminal offence, has very serious consequences, endangering public health and directly affecting people's lives.

We are put at risk by promoting a false sense of security (e.g. misleading information about treatments) and by promoting suspicion of the official guidelines and sources. Public can help break the fake news chain by: "Being mindful - fake news will often tell you what you want to hear with clickbait headlines.

Looking around - is the website trustworthy? Check the website's about page, mission and contact info. Checking the sources - is any other news source reporting on the same thing? How many sources does the story quote?

Photo search - is the news you are reading accompanied by a photo that strikes you as out of context? Run an online search, it might be your clue towards figuring out that this is an example of misinformation.

Checking the date - some news outlets republish old posts or promote old news as current stories. Check the publication date of the article and check if the timeline it refers to makes sense.

Turning to the experts - go to reputable websites, such as the World Health Organization [2].

Conclusion. Pro-Russian media spreads disinformation about different folks surrounding either the Covid-19 vaccine methods and effectiveness or the treatment itself. Disinformation during the pandemic crisis situation scares the public even more. Some headlines absolutely deny the problem of the 
coronavirus while the other part of the fake news contains such information as the invention of a vaccine against SARS-CoV-2 which is not corresponding the truth. What we clearly see is that the Corona virus has created a strong ground to circulate and spread disinformation. In the pandemic situation the Kremlin still uses panic and fear in the public for political goals which forces countries that are targeted by Russian propaganda to fight both the coronavirus pandemic and the Fake news.

EU analysis and the analysis of independent disinformation experts show that despite these statebacked recommendations and initiatives, most online fake news about Covid-19 have huge impact on average EU citizens looking for advice and support from others on social media.

\section{References}

1. Coronavirus: Russia denies spreading US conspiracy on social media / BBC News. 2020. URL: https://www.bbc.com/news/world-us-canada51599009.

2. Covid-19, Fake News / Europol. 2020. URL: https://www.europol. europa.eu/ covid-19/covid19-fake-news?fbclid=IwAR2kH38XOUmhd4b1r ZdxmgKqMln-k6bYpSkLqiX9BOB9bR3gmNaRhnoTiQ.

3. Fake News or the Truth? Russia Cracks Down on Virus Postings / Associated Press. 2020. URL: https://www.voanews.com/europe/fake-news-ortruth-russia-cracks-down-virus-postings.

4. Herd G.P. COVID-19, Russian Responses, and President Putin's Operational Code / Graeme Herd // George C. Marshall European Center for Security Studies. 2020. URL: https://www. marshallcenter.org/en/publications/security-insights/ covid-19-russian-responses-and-president-putinsoperational-code.

5. Kintsurashvili T., Ratiani N. «Russian Cluster» of disinformation and its «internal spread» in Georgia / Myth Detector Lab. 2020. URL: http://www.mythdetector.ge/en/myth/russiancluster-disinformation-and-its-internal-spreadgeorgia?fbclid=IwAR0z Nr2S5VfX3IgGxkJHI3dGfjKZg63d8v0PvLLA3ek cacqdzBZ1lw8KwRI.

6. Mamuladze N. Russian Propaganda and the Novel Coronavirus / Factcheck. 2020. URL: https:// factcheck.ge/en/story/38406-russian-propagandaand-the-novel-coronavirus?fbclid=IwAR1K2XF0 wrTsCd9FlkqSOzcu2ROV2kNQWQCH-XGwXrv O5tw7A5L5AKvKWEE.

7. Mshvidobadze K. Trio Pandemic Propaganda: How China, Russia and Iran Are Targeting the West / Georgian Foundation For Strategic and International Studies. 2020. URL: https://www.gfsis. org/blog/view/1067?fbclid= IwAR2fPhpDKatgb A13 Aqnuo W0XSxEPrYcMYAn8odi8 MSnn5e 91Si9-uf9GquU.

8. Rankin J. Russian media spreading Covid-19/ The Guardian. 2020. URL: https://www. theguardian.com/world/2020/mar/18/russian-mediaspreading-covid-19-disinformation.

9. Scott M. Russia and China push «fake news» aimed at weakening Europe: report / Factcheck. 2020. URL: https://www.politico.eu/article/russiachina-disinformation-coronavirus-covid19facebook-google/.

10. Данелия Н. Дезинформация распространилась

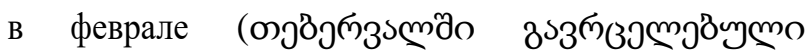
œj6обозмпдызоs) / Mediachecker. 2020. URL: https://www. radiotavisupleba.ge/

11. Датишвили С. Коронавирус и российская дезинформация, борьба на два фронта / Радио Свобода. 2020. URL: https://www. radiotavisupleba.ge/

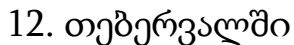

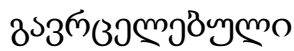
мэ\%обозмпазъоз / Mediachecker. 2020. URL: https://www.mediachecker.ge/ka/siakhleebi/a rticle/80637-thebervalshi-gavrcelebulidezinformacia.

\section{References}

1. Coronavirus: Russia denies spreading US conspiracy on social media / BBC News. 2020. URL: https://www.bbc.com/news/world-us-canada51599009.

2. Covid-19, Fake News / Europol. 2020. URL: https://www.europol. europa.eu/ covid-19/covid19-fake-news?fbclid=IwAR2kH38XOUmhd4b1r ZdxmgKqMln-k6bYpSkLqiX9BOB9bR3gmNaRhnoTiQ.

3. Fake News or the Truth? Russia Cracks Down on Virus Postings / Associated Press. 2020. URL: 
https://www.voanews.com/europe/fake-news-ortruth-russia-cracks-down-virus-postings.

4. Herd G.P. COVID-19, Russian Responses, and President Putin's Operational Code / Graeme Herd // George C. Marshall European Center for Security Studies. 2020. URL: https://www. marshallcenter.org/en/publications/security-insights/ covid-19-russian-responses-and-president-putinsoperational-code.

5. Kintsurashvili T., Ratiani N. «Russian Cluster» of disinformation and its «internal spread» in Georgia / Myth Detector Lab. 2020. URL: http://www.mythdetector.ge/en/myth/russiancluster-disinformation-and-its-internal-spreadgeorgia?fbclid=IwAR0z Nr2S5VfX3IgGx kJHI3d GfjKZg63d8v0PvLLA3ekcacqdzBZ1lw8KwRI.

6. Mamuladze N. Russian Propaganda and the Novel Coronavirus / Factcheck. 2020. URL: https:// factcheck.ge/en/story/38406-russian-propagandaand-the-novel-coronavirus?fbclid=IwAR1K2 XF0wrTsCd9FlkqS0zcu2ROV2kNQWQCH-XGw XrvO5tw7A5L5AKvKWEE.

7. Mshvidobadze K. Trio Pandemic Propaganda: How China, Russia and Iran Are Targeting the West / Georgian Foundation For Strategic and International Studies. 2020. URL: https://www.gfsis. org/blog/view/1067?fbclid=IwAR2fPhpDKatgb
Al3 Aqnuo W0XSxEPrYcMY An8odi8 MSnn5e 91Si9-uf9GquU.

8. Rankin J. Russian media spreading Covid-19/ The Guardian. 2020. URL: https://www. theguardian.com/world/2020/mar/18/russian-mediaspreading-covid-19-disinformation.

9. Scott M. Russia and China push «fake news» aimed at weakening Europe: report / Factcheck. 2020. URL: https://www.politico.eu/article/russiachina-disinformation-coronavirus-covid19facebook-google/.

10. Danelija N. Dezinformacija rasprostranilas'

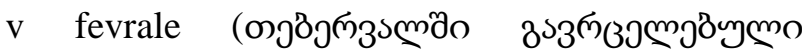
œj6обозмпдызоs) / Mediachecker. 2020. URL: https://www. radiotavisupleba.ge/

11. Datishvili C. Koronavirus i rossijskaja dezinformacija, bor'ba na dva fronta / Radio Svoboda. 2020. URL: https://www.radio tavisupleba.ge/

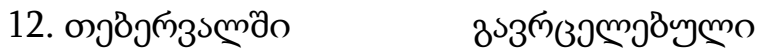
мэвобозмпаззоз / Mediachecker. 2020. URL: https://www.mediachecker.ge/ka/siakhleebi/a rticle/80637-thebervalshi-gavrcelebulidezinformacia. 


\title{
COVID-19 ТА ЙОГО ВПЛИВ НА ДЕЗІНФОРМАЦІЮ ТА ФЕЙКОВІ НОВИНИ
}

\author{
Міжнародний Чорноморський Університет \\ алея Давида Агмашенебелі, 2, 13 км., 0131, тбілісі, Грузія \\ E-mail: mikiashvilisalome@gmail.com
}

У статті автор хоче розкрити розуміння та особливості дезінформачії щодо коронавірусу та шкідливої для людей інформаиії, а також дослідити механізми, які СС та США використовують для боротьби із дезінформащією, щео надходить із Росії. Цю проблему досліджували С. Датишвілі, Г. Герд, Т. Кіниурашвілі, Н. Мамуладзе, К. Мшвідобадзе та інші вчені.

Мета дослідження полягає у критичній оцінці поширення дезінформаџї̈ різними зацікавленими державами та групами під час пандемії коронавірусу та ї̈ наслідків. Методологічну основу дослідження складають філософські, ідеологічні, загальнонаукові та спеціальні методи. Результатом дослідження став аналіз ефективності заходів, які вжсиваються країнами ЄС та США під час пандемії вірусу Корона для боротьби із потиренням дезінформаиії. Дискусія в статті торкнеться шляхів підвищення обізнаності про дезінформацію та Covid-19 для зменшення розповсюдження фальшивих новин, а також пошук дієвих методів, які слід вжити під час боротьби із поширенням дезінформаиії.

Пандемія коронавірусу була настільки непередбачуваною для світу, щэо той виявився зовсім не готовим до ї̈ наслідків. Тим не менше коронавірус породив нову еру в Інтернеті. Світ перейшов до існування у віртуальному режимі, що в свою чергу спричинило нові труднощі. Урядові та неурядові організації, приватні компанії та бізнес перейтли на режим дистанційної роботи. Таким чином $і$ кіберзлочиниі також стали більш активними. Зі зростанням кіберзлочинності кількість дезінформації, пов'язаної з державними інтересами, також зросла.

Понад 90\% світового населення перебуває в частковій або повній самоізоляиії. Заводи, торгові иентри, ресторани, кафе, кінотеатри та театри не працюють. Хоча світ, здається, зупинився, російські дезінформатори прачюють вдвічі важче, спрямовуючи теорії змови та фейкові новини під прикриттям нового коронавірусу.

Повідомлення спочатку з'являються в російських ЗМI, що згодом служить основою для грузинських 3МI. Інформачія розповсюджується систематично із залученням сторінок Facebook та конкретних людей, які часто озвучують повідомлення Кремля. Фальшиві новини про COVID-19, щяо ииркулюють у Грузії, мають політичний характер і поширюються відверто проросійськими, а також грузинськомовними виданнями.

Мотив розповсюдження фейкових новин є суто політичним, але поширення дезінформації щодо COVID-19, хоча і не завжди є кримінальним злочином, має дуже серйозні наслідки, загрожуючи здоров'ю населення та безпосередньо впливаючи на життя людей. У ситуації пандемії Кремль все ще використовує паніку та страх серед громадськості заради політичних цฺілей, щзо змушує крайни, на які націлена російська пропаганда, боротися як із пандемією коронавірусу, так $i$ з фейковими новинами. Нечесні новини про Covid-19 мають величезний вплив на пересічних громадян ЄС, які шукають поради та підтримки від інших у соиіальних мережах.

Ключові слова: дезінформачія; групи за інтересами; Cоvіd-19; пандемія; Росія; фейкові новини. 